\title{
Ecology of Phragmites australis and responses to tidal restoration
}

\author{
Randolph Chambers \\ College of William and Mary, rmcham@wm.edu
}

Laura A. Meyerson

Kimberly L. Dibble

Follow this and additional works at: https://scholarworks.wm.edu/asbookchapters

Part of the Terrestrial and Aquatic Ecology Commons

\section{Recommended Citation}

Chambers, R., Meyerson, L. A., \& Dibble, K. L. (2012). Ecology of Phragmites australis and responses to tidal restoration. Charles T. Roman and David M. Burdick (Ed.), Tidal Marsh Restoration: A Synthesis of Science and Management (pp. 81-96). Island Press. https://scholarworks.wm.edu/asbookchapters/72

This Book Chapter is brought to you for free and open access by the Arts and Sciences at W\&M ScholarWorks. It has been accepted for inclusion in Arts \& Sciences Book Chapters by an authorized administrator of W\&M ScholarWorks. For more information, please contact scholarworks@wm.edu. 


\title{
Ecology of Phragmites australis and Responses to Tidal Restoration
}

\author{
Randolph M. Chambers, Laura A. Meyerson, \\ and Kimberly L. Dibble
}

Tidal wetland restoration typically has as one of its primary goals the reestablishment of ecosystem-level functions and services to marsh habitats degraded by reductions in tidal flow. On a fundamental level, reduction or restriction of tidal flooding alters the wetland environment so dramatically that soils, hydrology, and vegetation are all impacted, so that wetland function de facto is changed. Luckily, restoration of tidal flows in many wetlands can reverse some of the functional changes caused by tidal restriction.

Smith and Warren (chap. 4, this volume) considered the more general topic of vegetative responses to tidal restoration. This chapter focuses on one notable plant species-Phragmites australis (common reed) - that has a checkered past with respect to its invasion, spread, and impacts in tidal wetlands. Although a number of Phragmites haplotypes may be native to North American wetlands, a putative, nonnative haplotype introduced sometime in the nineteenth century rapidly expanded into tidal wetlands of New England. The nonnative haplotype has since expanded across the entire continent of North America, wreaked havoc on wetland plant diversity, altered animal communities, and changed soil and hydrologic features of invaded wetlands, to the point where many wetland management programs specifically target the removal of nonnative Phragmites. Phragmites is fairly salt tolerant, but the species appears to be better adapted to high marsh and lower salinity conditions. Whether Phragmites invasion and expansion are causes or consequences of wetland alteration, restoration of tidal flows is often an effective tool for replacing the nonnative Phragmites with native vegetation adapted to more extensive flooding and elevated salinity. Within the broader context of wetland management in a time of coastal eutrophication and rising sea level, however, Phragmites-dominated wetlands can contribute valuable ecosystem 
functions and services that contribute to human and estuarine welfare. This chapter reviews the ecology of Phragmites australis, its legacy borne out of past alteration of tidal wetland habitats, and its future in a coastal landscape transformed by anthropogenic and other forces.

\section{Expansion of Phragmites into Tidal Wetlands}

A number of prior reviews have summarized the history of Phragmites expansion into tidal wetlands in North America (Marks et al. 1994; Chambers et al. 1999; Meyerson et al. 2009). For probably thousands of years prior to the industrial revolution, Phragmites was part of the mixed-plant community in some high marshes (Orson 1999). In the past two hundred years, however, the species has become more broadly distributed at local, regional, and national scales, forming extensive monocultures often extending into lower tidal elevations, especially in oligohaline and mesohaline marshes. In the coastal environment, Phragmites tends to grow densely around urban population centers (New York, NY; Boston, MA; Philadelphia, PA; Wilmington, DE; Baltimore, MD; and New Orleans, LA), suggesting the initial invasion and subsequent spread of a nonnative form of Phragmites was facilitated by shipping and boat traffic, or that disturbance of intertidal habitats (e.g., mosquito ditching, shoreline alteration) has been greatest in these developed regions. Phragmites is now extensive in coastal wetlands throughout New England, the focal region for this book.

Lelong et al. (2007) suggest the "sleeper-weed" phenomenon to describe the extended period of acclimatization of the introduced form of Phragmites prior to its recent and sudden appearance and spread into wetland habitats. Plants establish in a new location via either seedling or rhizome dispersal, then clonal growth via root and rhizome extension allows Phragmites to displace other species and inhibit the growth of competitors.

The first comprehensive work on genetic diversity of Phragmites in tidal wetlands of North America was completed by Saltonstall, who used variation in both chloroplast and nuclear DNA to identify thirteen haplotypes either native to North America or introduced in the recent past (Saltonstall 2002; Saltonstall 2003; Meadows and Saltonstall 2007). These two closely related lineages of Phragmites australis have been designated as subspecies by Saltonstall et al. (2004). Furthermore, based on past work, multiple introductions of the introduced haplotype M to North America seem likely (Saltonstall et al. 2010). If this proves indeed to be the case, genetic diversity of introduced Phragmites in North America may be higher in its introduced range, as is the case for other introduced grasses such as Phalaris arundinaceae (reed canarygrass) (Lavergne and Molofsky 
2007), potentially contributing to the highly invasive behavior of the introduced lineage.

Because the native and introduced subspecies are so closely related, it seems likely that they should be able to interbreed. However, to date no conclusive evidence for this has been detected in wild populations. Various researchers have speculated that this was due to a phenological barrier, but Meyerson and colleagues (2010) have demonstrated overlap of anthesis between multiple native and introduced populations both in the field and in a common garden experiment. In addition, they have also successfully produced hybrids of the native and introduced subspecies, although so far all viable offspring have introduced pollen parents and native seed parents suggesting unidirectional gene flow. Speculation persists as to why wild hybrids have not thus far been detected in tidal marshes and include reasons such as undersampling and outbreeding depression (Meyerson et al. 2010) and salinity constraints on germination and seedling growth (Bart and Hartman 2003). More recently, dozens of new native populations have been identified that are within range to interbreed with nonnative populations (Blossey and Hazelton, pers. comm.). These discoveries increase the possibility that wild hybrids will be found.

Introduction of the nonnative strain of Phragmites is considered a prerequisite for the invasion and spread of this species into tidal wetlands of New England and Atlantic Canada (Saltonstall 2002). Phragmites exhibits many characteristics of successful invasive species, summarized by Meyerson et al. (2009). As an early colonizer of disturbed environments, Phragmites typically establishes in wetlands that have been recently altered by human activities (Bart et al. 2006; Peterson and Partyka 2006). Physiologically, the nonnative haplotype exhibits a number of adaptations to tidal wetland habitats, including effective osmoregulation of rhizome-started plants in brackish water (Vasquez et al. 2005), tolerance to flooding and to toxic sulfide relative to freshwater species (Chambers et al. 2003), greater nutrient use efficiency (Saltonstall and Stevenson 2007), greater rates of photosynthesis and stomatal conductance (Mozdzer and Zieman 2010), greater rhizome growth (League et al. 2006), and decreased susceptibility to herbivory relative to native haplotypes (Park and Blossey 2008).

This is the enigma for tidal wetland restoration, in that many wetlands altered by human intervention - and thus targeted for restoration - have provided the optimum conditions to encourage Phragmites invasion and spread (Roman et al. 1984). Indeed, Niering and Warren (1980) considered the presence of Phragmites a signature of wetland alteration in New England tidal marshes. Even though Phragmites may become established in apparently pristine wetland sites, it is human facilitation of Phragmites introduction and spread that is most commonly 
observed (Bart et al. 2006). For much of the twentieth century, Phragmites was observed invading and spreading into tidal wetlands where some form of physical disturbance of wetland hydrology, soils, or plant community structure had recently occurred. Much like an early successional species, Phragmites is capable of exploiting small-scale "safe sites" commensurate with physical habitat disturbance (Bart and Hartman 2003). Once established, the plant expands primarily via clonal growth (Amsberry et al. 2000) and quickly becomes a dominant species.

Phragmites is found growing in different wetland types, but this summary focuses on the incursions of Phragmites into tidal marshes where alterations of tidal flow have occurred. Implicit in the discussion of the science and management of tidal flow restoration is the science and management of Phragmites, simply because the history of Phragmites invasion and spread is tied so closely with wetland alteration.

\section{Impacts of Phragmites in Tidal Wetlands}

Once established, dense stands of Phragmites may grow to heights exceeding 3 to 4 meters and physically prevent or displace native marsh vegetation, including Spartina alterniflora (smooth cordgrass), S. patens (salt meadow cordgrass), Distichlis spicata (spikegrass), Juncus romerianus (black needlerush), and other high marsh species, via competitive dominance for light and nutrients (Windham and Meyerson 2003; Meyerson et al. 2009) and perhaps allelopathy (Bains et al. 2009). Some of these changes in plant community structure are driven both by the presence of Phragmites and by the initial alteration of the wetland via restricted tidal flows. Phragmites modifies the biotic environment both at the soil surface and aboveground, effectively excluding potential competitors (Minchinton et al. 2006) and reducing species diversity (Lambert and Casagrande 2007; Lelong et al. 2007). Beyond the obvious changes in vegetation, however, Phragmitesdominated wetlands are significantly different from other tidal marshes in other ways.

\section{Soil Structure}

Phragmites invests a tremendous amount of carbon storage belowground, both as roots and as rhizomes. Bulk soil organic matter is tied up in both live and dead Phragmites tissues that effectively form a mat 5 to 20 centimeters thick. The Phragmites mat and accumulated litter sit atop the wetland soils; combined with enhanced sediment trapping, the wetland surface in a Phragmites-dominated tidal marsh tends to grow higher in elevation (Rooth et al. 2003). Further, the root and rhizome mat creates a more uniform surface elevation of the marsh, yielding less 
variation in microtopography and reducing the density of incipient channel formation (Lathrop et al. 2003). Interestingly, Phragmites is also capable of extending deep roots through shallow, saltier marsh pore water to plumb deeper freshwater lenses (Burdick et al. 2001).

In many wetlands where tidal flows have been reduced, however, decreased tidal flooding and, as a consequence, decreased salinity tend to encourage the introduction and expansion of Phragmites. These same, reduced flow conditions also tend to oxidize previously deposited wetland peat, so that soil elevation decreases relative to sea level. These wetlands with restricted tidal flows experience both subsidence associated with peat oxidation (Anisfeld, chap. 3, this volume) and increasing surface elevation associated with Phragmites root and rhizome deposition.

\section{Hydrology}

Especially in tidal wetlands where the flow of saline water has been inhibited, Phragmites is capable of establishing and expanding (Burdick and Konisky 2003). Beyond this initial human facilitation, however, Phragmites "engineers" wetland hydrology in a number of ways. First, because Phragmites grows in dense stands, movement of tidal water across wetland surfaces is slowed, and hydroperiods are decreased as a consequence. Not only is the time of inundation typically reduced in wetlands where Phragmites has been introduced; the depth of flooding is also shallower. As a result, the Phragmites rhizosphere remains oxidized in even saline wetlands for extended periods of time. During neap tidal phases, Phragmitesdominated tidal wetlands may not flood at all (Chambers et al. 2003). These long periods of rhizosphere exposure are apparently sufficient to offset oxygen or carbon stress during more extensive periods of inundation during spring tidal phases.

In many tidal wetlands Phragmites competes with Spartina spp. that are $\mathrm{C}_{4}$ plants adapted to reducing water loss in a hypersaline environment. $\mathrm{As}_{\text {a }} \mathrm{C}_{3}$ plant, evapotranspirative fluxes by Phragmites pull more water from the soils than $\mathrm{C}_{4}$ plants and tend to draw down the water table. Water evaporated from the leaf surfaces is replaced by root uptake of soil water below the soil surface; in turn, soil water is replaced by infiltration. Relative to $\mathrm{C}_{4}$-dominated wetlands, the turnover of pore water is much faster in Phragmites-dominated wetlands, which may facilitate both the flushing of toxins and the delivery of nutrient- and oxygen-rich water into the rhizosphere. Collectively, these hydrologic characteristics appear to create positive feedbacks of decreased flooding stress and increased plant growth that allow Phragmites to establish and thrive in wetlands with reduced or restricted tidal flooding. 


\section{Animals}

Numerous studies have examined the possible change in habitat function and value as introduced Phragmites expands through tidal-marsh ecosystems. Some have reported declines in juvenile and larval habitat as the Phragmites invasion progresses, especially for Fundulus heteroclitus (mummichog; Able et al. 2003; Able and Hagan 2003; Osgood et al. 2003; Hunter et al. 2006). F. heteroclitus is the most abundant species in these habitats and is considered a major conduit for transfer of marsh, epibenthic, and water column production to higher trophic levels (Kneib 1986). In Phragmites-dominated tidal marshes, fish species and crustaceans may not be reduced in terms of diversity and total abundance (Warren et al. 2001). Fell et al. (2003) suggested Phragmites might be a better nursery habitat for fish and macroinvertebrates relative to oligohaline marshes vegetated by other plant species. Similarities in nekton abundance have also been shown for Phragmites and non-Phragmites marshes at similar elevation and flooding frequency (Osgood et al. 2006), suggesting the change in faunal community structure in tidally restricted wetlands is not driven by Phragmites per se but more by reduction in tidal flooding. Carbon, nitrogen, and sulfur from Phragmites wetlands is detected in estuarine food webs (Wainright et al. 2000; Wozniak et al. 2006) and contributes to the production of marine resident and transient species (Weinstein et al. 2000), but the relative importance of Phragmites plant detritus in supporting secondary production in adjacent estuaries has not been quantified.

Phragmites-dominated tidal wetlands in Connecticut have been shown to exhibit fewer birds overall and fewer state-listed species relative to short-grass marshes dominated by Spartina and other species (Benoit and Askins 1999). In a recent study in Rhode Island, foraging egrets were never observed in Phragmites stands (Trocki and Paton 2006). Another study found that neither blue herons nor egrets nested in Phragmites stands, but that Phragmites patches were critical nesting habitat for some wading birds and also provided a buffer from human disturbance (Parsons 2003). As one component of a wetland matrix including other vegetation, mudflats, and tidal creeks, Phragmites stands appear to serve as valuable avian habitat for numerous species, including some marsh specialists. In many degraded wetlands with restricted tidal flow, however, Phragmites monocultures are not utilized as extensively, an outcome related both to the loss of other habitat types in Phragmites monocultures and perhaps to the absence of tidal exchange.

\section{Biogeochemistry/Nutrient Cycling}

Phragmites is a colonizing, early successional species, but it exhibits some characteristics typical of a mature, climax species. So, for example, nutrients tend to be 
recycled fairly tightly in Phragmites stands, and most nutrients are stored in organic form in the mass of live and standing dead material (Windham and Meyerson 2003). The total standing stock of nitrogen in a Phragmites-dominated wetland is very large; thus the nitrogen requirements for the plant are large (Meyerson et al. 2000). Silliman and Bertness (2004) were first to associate local nitrogen enrichment from shoreline development with Phragmites invasion. Since then, a number of studies have verified the association of Phragmites establishment and spread with local nitrogen enrichment from adjacent upland environments. Wigand and McKinney (2007) used stable isotopic analysis of plant tissue to show that Phragmites incorporates nitrogen derived from different types of shoreline development. King et al. (2007) found positive correlations between coastal urbanization and nitrogen content of Phragmites, a proxy for nitrogen availability/ uptake. Chambers et al. (2008) found that Phragmites occurrence along the shoreline of Chesapeake Bay was correlated with agriculture in the adjacent uplands. Although other mechanisms are plausible, collectively these studies indicate that nutrients derived from upland sources may supplement the limiting pool of available nitrogen in wetlands. Especially if these high marsh locations have experienced localized disturbance such as peat disturbance and rhizome burial (Bart et al. 2006), the combination with nutrient enrichment may facilitate the invasion and spread of Phragmites.

Phragmites appears to exploit forms of nitrogen that are not as readily available to other wetland species. Mozdzer et al. (2010) found that both Phragmites and Spartina alterniflora were able to incorporate dissolved organic nitrogen species, but that the introduced Phragmites had significantly greater urea assimilation rates than either native Phragmites or S. alterniflora. Ecophysiological differences including larger nitrogen demands and overall greater photosynthetic rates may contribute to the success of the introduced haplotype in North American tidal wetlands, especially in areas of nitrogen enrichment (Mozdzer and Zieman 2010). To this end, watershed-derived nitrogen from freshwater runoff, groundwater discharge, and atmospheric deposition all may contribute to satisfying nitrogen demand and facilitate Phragmites establishment and spread in coastal wetlands.

The combination of restricted tidal flows and Phragmites growth tends to draw down the water table; thus the soils are relatively oxidized. Oxidation of reduced sulfur compounds (iron monosulfide and pyrite) in Phragmites-dominated marsh soils can create slight to moderate acidity in the rhizosphere. Metal oxides and manganese and iron plaques may form on the roots and rhizomes of Phragmites where phosphorus may be immobilized. These plaques do not seem to limit plant growth (Batty et al. 2002), although Packett and Chambers (2006) measured high foliar N:P molar ratios of over 50:1 in Phragmites marshes, suggestive of phosphorus limitation. In Phragmites marshes with restricted tidal flows, the physical 
growth form of Phragmites (Windham and Meyerson 2003; Minchinton et al. 2006) and apparent sequestration of a large nutrient pool together are sufficient to exclude most other plant species.

\section{Responses of Phragmites to Tidal Restoration}

Implicit in tidal marsh restoration is a relative increase in the exposure of marsh soils to flooding by saline water, accomplished via larger culverts, breaching of dikes, or ditch-plugging (Konisky et al. 2006). Simenstad et al. (2006) ask what we are restoring to, noting that shifts in both the restoring landscape and external forcing functions shaping that landscape have to be considered along with the goals of restoration. With respect to Phragmites, the object of most tidal restoration efforts is to eliminate the nonnative species while encouraging reestablishment of a tidal wetland dominated by native marsh vegetation. Unfortunately, restoration pathways are not simply the reverse of prior degradation pathways (Zedler and Kercher 2005); that is, a hysteretic effect exists for which the wetland may fail to return to its original state once the external force (in this case, the tidal restriction or invasive species Phragmites) is removed (Valega et al. 2008). To some extent, tidal wetlands will self-organize when tidal flows are restored and Phragmites dies back, but some constraints may exist associated with respect to factors both within and external to the wetland. So, for example, wetland soil structure may be altered so dramatically that the "restored" vegetation community is different from that prior to Phragmites invasion. The plant community outcome after reflooding may be a unique result of species interactions involving the relative stress tolerance to physical factors and competitive strength (Konisky and Burdick 2004). In this study, for example, Phragmites continued growing even in higher-salinity zones with regular flooding. Finally, the wetland ecosystem may exhibit sufficient heterogeneity that only some portions successfully "restore" (Callaway 2005). The surrounding upland watershed and regional environment may have changed to the extent that the "before Phragmites" wetland type cannot be a realistic end point for restoration (Warren et al. 2002).

Nevertheless, success stories documenting restoration of tidal flows leading to reduced or eliminated growth of introduced Phragmites are common. Despite its remarkable success in degraded polyhaline and even some euhaline marshes, Phragmites is a brackish marsh species typically occurring in the high marsh. Phragmites owes its success in degraded marshes to the reduction in tidal flows that converts a flooded salt marsh to a more exposed brackish marsh. In this sense, restoration of tidal flows does offer opportunity to allow tidal water, salt, and sulfide to stress the invader and encourage native halophytic vegetation (Chambers et al. 2003; Konisky and Burdick 2004). More saltwater tends to eliminate many of 
the advantages Phragmites has in wetlands with restricted tidal flow, and the species moves to higher elevations (Smith et al. 2009). Warren et al. (2002) summarized twenty years of science and management of marsh restoration in Connecticut, noting that "recovery rates" - assessed in part as reduction in various plant parameters related to Phragmites vigor and coverage - varied more with restoration hydroperiod than with the salinity of the tidal water. Phragmites reduction was more rapid in wetlands with lower elevation, longer hydroperiod, and higher water table. Low marsh habitats invaded by Phragmites tended to restore to S. alterniflora wetlands in just a few years after reintroduction of tidal flows, whereas reduction in Phragmites expanse in higher marsh habitats took one to two decades. Return of marsh invertebrates, fish, and avian fauna was variable and did not always parallel the rates of recovery of native vegetation (Brawley et al. 1998).

Konisky et al. (2006) reported monitoring results from thirty-six tidal salt marsh restoration projects in Maine and found that replacement of brackish species including Phragmites and recovery of halophytes was typically observed three or more years following restoration. Restoration of tidal flushing in a salt marsh in Ipswich, Massachusetts, led to variable decreases in Phragmites vigor after four years (Buchsbaum et al. 2006). In Rhode Island, Roman et al. (2002) found that restoration of tidal flow in a restricted marsh significantly decreased Phragmites abundance and height after just one year, and that the entire vegetation community was converging toward that of an adjacent, unrestricted tidal marsh. Tidal exchange has been enhanced at over sixty-five wetland sites along the Connecticut coast, with reduction or elimination of Phragmites one of the major outcomes (Warren et al. 2002; Rozsa, chap. 8, this volume). Based on these studies, restoration of full wetland functionality for higher trophic levels including fish and birds may take decades (Fell et al. 2000). Further, restoration of tidal flows and elimination of Phragmites may yield other unintended consequences, as found in a Rhode Island marsh where greater nest failure by sharp-tailed sparrows initially was observed owing to flooding of the nests (DeQuinzio et al. 2002).

Restoration success of tidal marshes invaded by Phragmites has primarily been measured by changes in both plant and nekton communities. Marshes with restricted tidal flow may support large numbers of nekton, but the restrictions limit contributions of those nekton to estuarine productivity (Eberhardt et al. 2011). Reducing restrictions and enhancing tidal flooding typically increase the abundance and diversity of fishes and crustaceans (Roman et al. 2002; Jivoff and Able 2003; Able et al. 2004), and increase the support of the estuarine food web (Wozniak et al. 2006). In fact, nekton use of the restored marsh surface may occur before Phragmites is replaced (James-Pirri et al. 2001), with restoration of the most restricted wetland sites exhibiting the most dramatic shift in nekton assemblages (Raposa and Roman 2003). In other studies, however, changes in nekton could 
not be demonstrated as a result of tidal restoration and reduction in growth of Phragmites (Buchsbaum et al. 2006; Raposa 2008), suggesting that nekton abundance and diversity are not directly tied to the presence or vigor of Phragmites.

Most successful tidal restoration programs in polyhaline wetlands have also been successful Phragmites removal efforts, but many tidally restricted salt marshes have been opened to tidal flow already; that is, fewer opportunities for restoration of restricted salt marshes remain in New England. For oligohaline and mesohaline wetlands, the timescale for Phragmites removal postrestoration of tidal flow is variable (Buchsbaum et al. 2006) and may be on the order of decades, if at all (Warren et al. 2002). Nationally, more opportunities exist for restoring tidal flows to wetlands in which Phragmites has not yet fully invaded (e.g., the extensive diked tidelands along the southeastern US coast). In these marshes, tidal restoration can perhaps prevent, rather than cure, invasion of nonnative Phragmites.

\section{Future of Phragmites}

As most scientists and managers realize, the objective of tidal wetland restoration is not necessarily to eliminate Phragmites but to control its dominance. The general tidal marsh restoration goal is to restore specific functions and services, some of which may be provided by Phragmites. Invasion and spread of Phragmites historically have been viewed in a negative sense because the functions and ecosystem services of "pre-Phragmites" wetlands are deemed more valuable (Hershner and Havens 2008), yet some Phragmites wetlands do provide important ecosystem services, including shoreline stabilization in a time of rising sea level, energy dissipation during storm surges, and rapid nutrient uptake during a time of coastal eutrophication (Ludwig et al. 2003). None of these services are provided by native Phragmites that historically has been a minor component of tidal wetland communities; beyond the argument for maintaining native diversity, its future in New England tidal marshes is in doubt. Given the ongoing transformation of the coastal landscape driven by an expanding human population, global climate change, and other environmental pressures, the nonnative haplotype of Phragmites may become more valued in New England and Atlantic Canada tidal marshes during the twenty-first century.

\section{Acknowledgments}

RMC acknowledges funding from USDA-CSREES grant no. 2003-35320-13395; LAM from USDA Agricultural Experiment Station grant no. 0208537 and the Michael R. Paine Conservation Trust; KLD from the NSF Coastal Institute IGERT Project, NOAA National Estuarine Research Reserve System, EPA STAR 
graduate fellowship program, P.E.O. International, Rhode Island Natural History Survey, The Nature Conservancy of Rhode Island, and the Northeast Aquatic Plant Management Society.

\section{REFERENCES}

Able, K. W., and S. M. Hagan. 2003. "Impact of Common Reed, Phragmites australis, on Essential Fish Habitat: Influence on Reproduction, Embryological Development, and Larval Abundance of Mummichog (Fundulus heteroclitus)." Estuaries 26:40-50.

Able, K. W., S. M. Hagan, and S. A. Brown. 2003. "Mechanisms of Marsh Habitat Alteration due to Phragmites: Response of Young-of-the-Year Mummichog (Fundulus heteroclitus) to Treatment for Phragmites Removal." Estuaries 26:484-94.

Able, K. W., D. M. Nemerson, and T. M. Grothues. 2004. "Evaluating Salt Marsh Restoration in Delaware Bay: Analysis of Fish Response at Former Salt Hay Farms." Estuaries 27:58-69.

Amsberry, L., M. A. Baker, P. J. Ewanchuk, and M. D. Bertness. 2000. “Clonal Integration and the Expansion of Phragmites australis." Ecological Applications 10:1110-18.

Bains, G., A. S. Kumar, T. Rudrappa, E. Alff, T. E. Hanson, and H. P. Bais. 2009. "Native Plant and Microbial Contributions to a Negative Plant-Plant Interaction." Plant Physiology 151:2145-51.

Bart, D., and J. M. Hartman. 2003. “The Role of Large Rhizome Dispersal and Low Salinity Windows in the Establishment of Common Reed, Phragmites australis, in Salt Marshes: New Links to Human Activities." Estuaries 26:436-43.

Bart, D. M., D. Burdick, R. Chambers, and J. Hartman. 2006. "Human Facilitation of Phragmites australis Invasions in Tidal Marshes: A Review and Synthesis." Wetland Ecology and Management 14:53-65.

Batty, L. C., A. J. M. Baker, and B. D. Wheeler. 2002. "Aluminum and Phosphate Uptake by Phragmites australis: The Role of Fe, Mn and Al Root Plaques." Aquatic Botany 89:443-49.

Benoit, L. K., and R. A. Askins. 1999. "Impact of the Spread of Phragmites on the Distribution of Birds in Connecticut Marshes." Wetlands 19:194-208.

Brawley, A. H., R. S. Warren, and R. A. Askins. 1998. "Bird Use of Restoration and Reference Marshes within the Barn Island Wildlife Management Area, Stonington, Connecticut, USA." Environmental Management 22:625-33.

Buchsbaum, R. N., J. Catena, E. Hutchins, and M. J. James-Pirri. 2006. "Changes in Salt Marsh Vegetation, Phragmites australis, and Nekton Response to Increased Tidal Flushing in a New England Salt Marsh." Wetlands 26:544-57.

Burdick, D. M., and R. A. Konisky. 2003. "Determinants of Expansion for Phragmites australis, Common Reed, in Natural and Impacted Coastal Marshes." Estuaries 26:407-16.

Burdick, D. M., R. Buchsbaum, and E. Holt. 2001. "Variation in Soil Salinity Associated with Expansion of Phragmites australis in Salt Marshes." Environmental and Experimental Botany 46:247-61. 
Callaway, J. C. 2005. “The Challenge of Restoring Functioning Salt Marsh Ecosystems.” Journal of Coastal Research 40:24-36.

Chambers, R. M., L. A. Meyerson, and K. Saltonstall. 1999. "Expansion of Phragmites australis into Tidal Wetlands of North America." Aquatic Botany 64:261-73.

Chambers, R. M., D. T. Osgood, D. J. Bart, and F. Montalto. 2003. "Phragmites australis Invasion and Expansion in Tidal Wetlands: Interactions among Salinity, Sulfide, and Hydrology." Estuaries 26:398-406.

Chambers, R. M., K. J. Havens, S. Killeen, and M. Berman. 2008. "Common Reed Phragmites australis Occurrence and Adjacent Land Use along Estuarine Shoreline in Chesapeake Bay." Wetlands 28:1097-1103.

DiQuinzio, D. A., P. W. C. Paton, and W. R. Eddleman. 2002. "Nesting Ecology of Saltmarsh Sharp-Tailed Sparrows in a Tidally Restricted Salt Marsh." Wetlands 22:179-85.

Eberhardt, A. L., D. M. Burdick, and M. Dionne. 2011. "The Effects of Road Culverts on Nekton in New England Salt Marshes: Implications for Tidal Restoration." Restoration Ecology 9:776-85.

Fell, P. E., R. S. Warren, and W. A. Niering. 2000. "Restoration of Salt and Brackish Tidelands in Southern New England." Pp. 845-58 in Concepts and Controversies in Tidal Marsh Ecology, edited by M. P. Weinstein and D. A. Kreeger. Boston, MA: Kluwer Academic.

Fell, P. E., R. S. Warren, J. K. Light, R. L. Lawson Jr., and S. M. Fairley. 2003. “Comparison of Fish and Macroinvertebrate Use of Typha angustifolia, Phragmites australis, and Treated Phragmites Marshes along the Lower Connecticut River." Estuaries 26:534-51.

Hershner, C., and K. J. Havens. 2008. "Managing Invasive Aquatic Plants in a Changing System: Strategic Consideration of Ecosystem Services." Conservation Biology 22:544-50.

Hunter, K. L., D. A. Fox, L. M. Brown, and K. W. Able. 2006. "Responses of Resident Marsh Fishes to Stages of Phragmites australis Invasion in Three Mid Atlantic Estuaries." Estuaries and Coasts 29:487-98.

James-Pirri, M. J., K. B. Raposa, and J. G. Catena. 2001. "Diet Composition of Mummichogs, Fundulus heteroclitus, from Restoring and Unrestricted Regions of a New England (USA) Salt Marsh.” Estuarine, Coastal and Shelf Science 53:205-13.

Jivoff, P. R., and K. W. Able. 2003. "Blue Crab, Callinectes sapidus, Response to the Invasive Common Reed, Phragmites australis: Abundance, Size, Sex Ratio, and Molting Frequency." Estuaries and Coasts 26:587-95.

King, R. S., W. V. Deluca, D. F. Whigham, and P. P. Marra. 2007. “Threshold Effects of Coastal Urbanization on Phragmites australis (Common Reed) Abundance and Foliar Nitrogen in Chesapeake Bay." Estuaries and Coasts 30:469-81.

Kneib, R. T. 1986. "The Role of Fundulus heteroclitus in Salt Marsh Trophic Dynamics." American Zoologist 26:259-69.

Konisky, R. A., and D. M. Burdick. 2004. "Effects of Stressors on Invasive and Halophytic Plants of New England Salt Marshes: A Framework for Predicting Response to Tidal Restoration." Wetlands 24:434-47. 
Konisky, R. A., D. M. Burdick, M. Dionne, and H. A. Neckles. 2006. "A Regional Assessment of Salt Marsh Restoration and Monitoring in the Gulf of Maine." Restoration Ecology 14:516-25.

Lambert, A. M., and R. A. Casagrande. 2007. "Characteristics of a Successful Estuarine Invader: Evidence of Self-Compatibility in Native and Non-native Lineages of Phragmites australis." Marine Ecology Progress Series 337:299-301.

Lathrop, R. G., L. Windham, and P. Montesano. 2003. "Does Phragmites Expansion Alter the Structure and Function of Marsh Landscapes? Patterns and Processes Revisited." Estuaries 26:423-35.

Lavergne, S., and J. Molofsky. 2007. "Increased Genetic Variation and Evolutionary Potential Drive the Success of an Invasive Grass." Proceedings of the National Academy of Sciences 104:3883-88.

League, M. T., E. P. Colbert, D. M. Seliskar, and J. L. Gallagher. 2006. "Rhizome Growth Dynamics of Native and Exotic Haplotypes of Phragmites australis (Common Reed)." Estuaries and Coasts 29:269-76.

Lelong, B., C. Lavoie, Y. Jodoin, and F. Belzile. 2007. "Expansion Pathways of the Exotic Common Reed (Phragmites australis): A Historical and Genetic Analysis." Diversity and Distributions 13:430-37.

Ludwig, D. F., T. J. Iannuzzi, and A. N. Esposito. 2003. "Phragmites and Environmental Management: A Question of Values." Estuaries and Coasts 26:624-30.

Marks, M. B., B. Lapin, and J. Randall. 1994. "Phragmites australis (P. communis): Threats, Management, and Monitoring." Natural Areas Journal 14:285-94.

Meadows, R. E., and K. Saltonstall. 2007. "Distribution of Native and Non-native Populations of Phragmites australis in Oligohaline Marshes of the Delmarva Peninsula and Southern New Jersey." Journal of the Torrey Botanical Society 134:99-107.

Meyerson, L. A., K. Saltonstall, L. Windham, E. Kiviat, and S. Findlay. 2000. “A Comparison of Phragmites australis in Freshwater and Brackish Marsh Environments in North America." Wetlands Ecology and Management 8:89-103.

Meyerson, L. A., K. Saltonstall, and R. M. Chambers. 2009. "Phragmites australis in Coastal Marshes of North America: A Historical and Ecological Perspective." Pp. 57-82 in Human Impacts on Salt Marshes: A Global Perspective, edited by B. R. Silliman, E. Grosholz, and M. D. Bertness. Berkeley: University of California Press.

Meyerson, L. A., D. V. Viola, and R. N. Brown. 2010. "Hybridization of Invasive Phragmites australis with a Native Subspecies in North America." Biological Invasions 12:103-11.

Minchinton, T. E., J. C. Simpson, and M. D. Bertness. 2006. "Mechanisms of Exclusion of Native Coastal Marsh Plants by an Invasive Grass." Journal of Ecology 94:342-54.

Mozdzer, T. J., and J. C. Zieman. 2010. "Ecophysiological Differences between Genetic Lineages Facilitate the Invasion of Non-native Phragmites australis in North American Atlantic Coast Wetlands." Journal of Ecology 98:451-58.

Mozdzer, T. J., J. C. Zieman, and K. J. McGlathery. 2010. “Nitrogen Uptake by Native and Invasive Temperate Coastal Macrophytes: Importance of Dissolved Organic Nitrogen." Estuaries and Coasts 33:784-97. 
Niering, W. A., and R. S. Warren. 1980. "Vegetation Patterns and Processes in New England Salt Marshes." BioScience 30:301-7.

Orson, R. 1999. "A Paleoecological Assessment of Phragmites australis in New England Tidal Marshes: Changes in Plant Community Structure during the Last Millennium.” Biological Invasions 1:149-58.

Osgood, D. T., D. J. Yozzo, R. M. Chambers, D. Jacobson, T. Hoffman, and J. Wnek. 2003. "Tidal Hydrology and Habitat Utilization by Resident Nekton in Phragmites and Non-Phragmites Marshes.” Estuaries 26:522-33.

Osgood, D. T., D. J. Yozzo, R. M. Chambers, S. Pianka, C. LePage, and J. Lewis. 2006. "Patterns of Habitat Utilization by Resident Nekton in Phragmites and Typha Marshes of the Hudson River Estuary." American Fisheries Society Symposium 51:151-73.

Packett, C. R., and R. M. Chambers. 2006. "Distribution and Nutrient Status of Haplotypes of the Marsh Grass Phragmites australis along the Rappahannock River in Virginia." Estuaries and Coasts 29:1222-25.

Park, M. G., and B. Blossey. 2008. "Importance of Plant Traits and Herbivory for Invasiveness of Phragmites australis (Poaceae)." American Journal of Botany 95:1557-68.

Parsons, K. C. 2003. "Reproductive Success of Wading Birds Using Phragmites Marsh and Upland Nesting Habitats." Estuaries 26:596-601.

Peterson, M. S., and M. L. Partyka. 2006. "Baseline Mapping of Phragmites australis (Common Reed) in Three Coastal Mississippi Estuarine Basins." Southeastern Naturalist 5:747-56.

Raposa, K. B. 2008. "Early Ecological Responses to Hydrologic Restoration of a Tidal Pond and Salt Marsh Complex in Narragansett Bay, Rhode Island." Journal of Coastal Research 55:180-92.

Raposa, K. B., and C. T. Roman. 2003. "Using Gradients in Tidal Restriction to Evaluate Nekton Community Responses to Salt Marsh Restoration.” Estuaries 26:98-105.

Roman, C. T., W. A. Niering, and R. S. Warren. 1984. "Salt Marsh Vegetation Changes in Response to Tidal Restriction." Environmental Management 8:141-50.

Roman, C. T., K. B. Raposa, S. C. Adamowicz, M. J. James-Pirri, and J. G. Catena. 2002. "Quantifying Vegetation and Nekton Response to Tidal Restoration of a New England Salt Marsh.” Restoration Ecology 10:450-60.

Rooth, J. E., J. C. Stevenson, and J. C. Cornwell. 2003. "Increased Sediment Accretion Rates following Invasion by Phragmites australis: The Role of Litter." Estuaries 26:475-83.

Saltonstall, K. 2002. "Cryptic Invasion by a Non-native Genotype of the Common Reed, Phragmites australis, into North America." Proceedings of the National Academy of Sciences 99:2445-49.

Saltonstall, K. 2003. "Genetic Variation among North American Populations of Phragmites australis: Implications for Management.” Estuaries 26:444-51.

Saltonstall, K., and J. C. Stevenson. 2007. "The Effect of Nutrients on Seedling Growth of Native and Introduced Phragmites australis." Aquatic Botany 86:331-36.

Saltonstall, K., P. M. Peterson, and R. Soreng. 2004. "Recognition of Phragmites australis Subsp. americanus (Poaceae: Arundinaceae) in North America: Evidence from Morphological and Genetic Analyses." Sida 21:683-92. 
Saltonstall, K., A. Lambert, and L. A. Meyerson. 2010. "Genetics and Reproduction of Common (Phragmites australis) and Giant Reed (Arundo donax). Invasive Plant Science and Management 3:495-505.

Silliman, B. R., and M. D. Bertness. 2004. "Shoreline Development Drives Invasion of Phragmites australis and the Loss of Plant Diversity on New England Salt Marshes." Conservation Biology 18:1424-34.

Simenstad, C., D. Reed, and M. Ford. 2006. "When Is Restoration Not? Incorporating Landscape-Scale Processes to Restore Self-Sustaining Ecosystems in Coastal Restoration." Ecological Engineering 26:27-39.

Smith, S. M., C. T. Roman, M. J. James-Pirri, K. Chapman, J. Portnoy, and E. Gwilliam. 2009. "Responses of Plant Communities to Incremental Hydrologic Restoration of a Tide-Restricted Salt Marsh in Southern New England (Massachusetts, U.S.A.)." Restoration Ecology 17:606-18.

Trocki, C. L., and P. W. C. Paton. 2006. "Assessing Habitat Selection by Foraging Egrets in Salt Marshes at Multiple Spatial Scales.” Wetlands 26:307-12.

Valega, M., A. I. Lillebo, M. E. Pereira, A. C. Duarte, and M. A. Pardal. 2008. "Long-Term Effects of Mercury in a Salt Marsh: Hysteresis in the Distribution of Vegetation following Recovery from Contamination." Chemosphere 71:765-72.

Vasquez, E. A., E. P. Glenn, J. J. Brown, G. R. Guntenspergen, and S. G. Nelson. 2005. "Salt Tolerance Underlies the Cryptic Invasion of North American Salt Marshes by an Introduced Haplotype of the Common Reed Phragmites australis (Poaceae)." Marine Ecology Progress Series 298:1-8.

Wainright, S. C., M. P. Weinstein, K. W. Able, and C. A. Currin. 2000. "Relative Importance of Benthic Microalgae, Phytoplankton, and the Detritus of Smooth Cordgrass Spartina alterniflora and the Common Reed Phragmites australis to Brackish-Marsh Food Webs." Marine Ecology Progress Series 200:77-91.

Warren, R. S., P. E. Fell, J. L. Grimsby, E. L. Buck, G. C. Rilling, and R. A. Fertik. 2001. "Rates, Patterns, and Impacts of Phragmites australis Expansion and Effects of Experimental Phragmites Control on Vegetation, Macroinvertebrates, and Fish within Tidelands of the Lower Connecticut River." Estuaries 24:90-107.

Warren, R. S., P. E. Fell, R. Rozsa, A. H. Brawley, A. C. Orsted, E. T. Olson, V. Swamy, and W. A. Niering. 2002. "Salt Marsh Restoration in Connecticut: 20 Years of Science and Management." Restoration Ecology 10:497-513.

Weinstein, M. P., S. Y. Litvin, K. L. Bosley, C. M. Fuller, and S. C. Wainright. 2000. “The Role of Tidal Salt Marsh as an Energy Source for Marine Transient and Resident Finfishes: A Stable Isotope Approach.” Transactions of the American Fisheries Society 129:797-810.

Wigand, C., and R. A. McKinney. 2007. "Varying Stable Nitrogen Isotope Ratios of Different Coastal Marsh Plants and Their Relationship with Wastewater Nitrogen and Land Use in New England, USA." Environmental Monitoring and Assessment 131:71-81.

Windham, L., and L. A. Meyerson. 2003. "Effects of Common Reed (Phragmites australis) Expansion on Nitrogen Dynamics of Tidal Marshes of the Northeastern U.S." Estuaries 26:452-64. 
Wozniak, A. S., C. T. Roman, S. C. Wainright, R. A. McKinney, and M. J. James-Pirri. 2006. "Monitoring Food Web Changes in Tide-Restored Salt Marshes: A Carbon Stable Isotope Approach." Estuaries and Coasts 29:568-78.

Zedler, J. B., and S. Kercher. 2005. "Wetland Resources: Status, Trends, Ecosystem Services, and Restorability." Annual Review of Environment and Resources 30:39-74. 